\title{
WEEDS AND THEIR ECOLOGICAL INDICATOR VALUES IN A LONG-TERM EXPERIMENT
}

\author{
NiKOlić, LJ. - ŠEREMEŠIĆ, S. - LJEVNAIĆ-MAŠIĆ, B. - LATKOVIĆ, D. - KONSTANTINOVIĆ, B. * \\ Faculty of Agriculture, University of Novi Sad, Trg Dositeja Obradovića 8, Novi Sad, Serbia \\ (phone: +381-21-485-3500; fax: +381-21-459-761) \\ *Corresponding author \\ e-mail: bojank@polj.uns.ac.rs; phone: +381-21-485-3315; fax: +381-21-450-616
}

(Received 12 $2^{\text {th }}$ Feb 2020; accepted 22 $2^{\text {nd }}$ May 2020)

\begin{abstract}
The floristic composition and weed infestation in wheat and maize crops were studied in a long-term field experiment in Serbia. A total of 35 weed species were identified, out of which 12 were common for both crops. The greatest floristic diversity (20 species) was found under wheat crops in unfertilized two-year rotation, while the lowest diversity ( 5 species) was determined in maize crops in monoculture and fertilized four-year rotation. The highest weed infestation was observed in wheat monoculture $\left(490.47 \mathrm{ind} / \mathrm{m}^{2}\right)$ and maize monoculture $\left(111.98 \mathrm{ind} / \mathrm{m}^{2}\right)$, while the lowest level of weed infestation $\left(17.31 \mathrm{ind} / \mathrm{m}^{2}\right)$ was observed in maize crops under intensive two-year rotation. Significant differences were found in the number of weed species and in the level of weed infestation between wheat and maize, as well as in the level of weed infestation in monoculture compared to other treatments of crop rotation for both crops. Ecological analysis indicated that the type of crop rotation and the species of crops have impact on the ecological characteristics of the studied area, which is reflected in different floristic composition and differences in the abundance of certain weeds.
\end{abstract}

Keywords: wheat, maize, ecological indices, crop rotation

\section{Introduction}

Agricultural production is facing a number of problems related to weed emergence in crops. Although intensive agricultural production offers effective combinations of chemical inputs used for weed control (Kim et al., 2002), it is necessary to make efforts at both local and global levels to reduce their use for the sake of preserving natural resources and ensuring food safety. Due to the exceptional plasticity and excellent adaptation of weeds to different anthropogenic influences, weed management and control produce best results when carried out continuously and adequately (Avola et al., 2008; Tyr, 2016). Apart from the usual cropping practices and application of chemicals, which have unfavourable impacts on human health and the environment, one of the most important preventive measures used for weed reduction is crop rotation, which is environmentally acceptable (Barberi et al., 1997; Suarez et al., 2001; Derksen et al., 2002; Nikolić et al., 2012, 2018; Wozniak and Soroka, 2015). Considering the longterm effects, cultivation of crops in crop rotation also leads to reduction of seed reserves in the soil, resulting in a lower level of weed infestation in a succeeding crop (Teasdale et al., 2004; Koocheki et al., 2009). Over a longer period of time, properly implemented crop rotation can have positive environmental effects on preservation of weed flora biodiversity, since crops are typical habitats for certain segetal weeds which are increasingly endangered due to intensive cropping practices (Hulina, 2005).

A particularly suitable method for determining the impact of crop rotation on weed infestation is a long-term experiment. The study presented in this paper was thus carried out in a long-term experiment with different crop rotation treatments, some of which 
were established 70 years ago. However, estimating the contribution of crop rotation to yield realization is difficult given the fact that weed control includes a number of different preventive and direct measures. As the effect of crop rotation is reflected in the cumulative effect on weed infestation, it is very important to follow the succession of the weed synusia, which is a topic scarcely studied in the literature. In addition, by determining weed communities specific for certain species, it is possible to select appropriate cropping practices to increase the anthropogenic pressure on these weeds and reduce their abundance.

Therefore, the aim of this paper was to analyse the weed flora, the level of weed infestation and the role of weeds as bioindicators in wheat and maize crops grown in different treatments of long-term crop rotation and fertilization. The obtained results can be used as a good basis for monitoring biodiversity of weeds and their role as bioindicators, as well as for determining the most favourable treatment of crop rotation for reducing weed infestation in wheat and maize crops.

\section{Materials and methods}

The floristic survey presented in this paper examined weeds in wheat (2010 year) and maize (2011 year) crops in long-term trials "Plodoredi" on the experimental field Rimski Šančevi (Serbia) of the Institute of Field and Vegetable Crops in Novi Sad $\left(45.19^{\circ} \mathrm{N}, 19.50^{\circ} \mathrm{E}\right)$. Crop rotation was arranged as a single crop rotation in which all crops were grown each year according to the experimental design, and plots were divided into three subplots $(90 \times 30 \mathrm{~m})$ representing the repetitions. Winter wheat and maize were continuously grown from the beginning of the trial $(1946 / 47)$, whereas soybean was introduced in 1969/70. The total area of the experimental field was 6.5 ha.

The trials were set on chernozem soil, which belongs to automorphic soil types, class A-C (humus-accumulative soil, the subtype chernozem on loess and loess-like sediments, the carbonate chernozem variety, medium-depth) (Škorić, 1985). This type of soil is characterised by slightly alkaline reaction with higher calcium content. It is rich in phosphorus and potassium, while the content of organic matter is lower than $3 \%$ as a result of intensive farming (Table 1).

Table 1. Basic chemical soil properties on the experimental field (mean values $\pm S D$ )

\begin{tabular}{|c|c|c|c|c|c|c|c|}
\hline \multirow{2}{*}{ Year } & \multicolumn{2}{|c|}{$\mathbf{H}$} & \multirow{2}{*}{$\underset{\%}{\mathrm{CaCO3}}$} & \multirow{2}{*}{$\begin{array}{c}\text { Organic matter } \\
\%\end{array}$} & \multirow{2}{*}{$\begin{array}{c}\text { Total } \\
\%\end{array}$} & \multirow{2}{*}{$\begin{array}{l}\text { Al-P2O5 } \\
\text { mg/100 g }\end{array}$} & \multirow{2}{*}{$\begin{array}{c}\text { Al-K2O } \\
\text { mg/100 g }\end{array}$} \\
\hline & in $\mathrm{KCl}$ & in $\mathrm{H} 2 \mathrm{O}$ & & & & & \\
\hline & $52 \pm 0.10$ & $8.1 \pm 0.12$ & $5.64 \pm 4.23$ & $2.7 \pm 0.38$ & $0.2 \pm 0.02$ & $65.93 \pm 61.50$ & $37.56 \pm 12.98$ \\
\hline
\end{tabular}

The long-term climate (1970-2009) at the investigated site (Rimski Šančevi experimental station) is continental, with an average annual precipitation of $617 \mathrm{~mm}$ and average annual temperature of $11.3{ }^{\circ} \mathrm{C}$ (HMZS, 2020). The climate is considered favorable for production of major crops: winter wheat, maize, soybean, sunflower etc. Compared with the long-term climate records, an increase in yearly average temperature and precipitation was observed. In the investigated period, both years were higher in average yearly temperatures, but 2009/10 was lower in precipitation and 2010/11 had above average precipitation compared to long-term average. The temperatures during the growing period, as well as for individual months, were very similar during 
investigated period. However, the timing and quantity of precipitation significantly differed, as 2009/10 had significantly higher precipitation than 2010/11, particularly in July (Fig. 1).

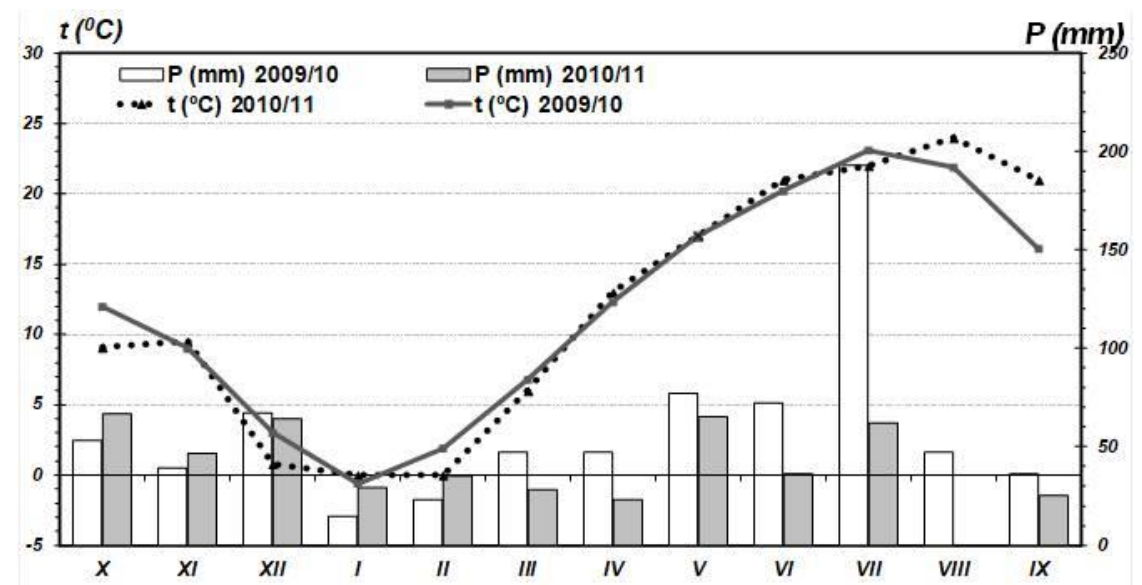

Figure 1. Medium monthly temperatures and precipitations in two production years (2009/10 and 2010/11)

The weed flora was investigated in the following experimental treatments: extensive (unfertilized) two-year rotation (maize-winter wheat) - E2 and extensive (unfertilized) three-year rotation (maize-soyabean-winter wheat) - E3, established in 1946/47, intensive (fertilized) two-year rotation (maize-winter wheat) - I2, intensive (fertilized) three-year rotation (maize-soyabean-winter wheat) - I3 with the application of organic and mineral fertilizers, established in 1969/70, three-year rotation with the application of organic fertilizers - (maize-soyabean-winter wheat) - IS3 (intensive three-year rotation), intensive four-year rotation with the application of organic and mineral fertilizers (maize-winter wheat-soyabean-sunflower) - I4, established in 1969/70, and monoculture of winter wheat - MoW and maize - MoM with the application of organic and mineral fertilizers, established in 1969/70. During the investigated period winter wheat variety Simonida was grown and maize hybrid NS640 created at the Institute of Field and Vegetable Crops Novi Sad. In the long-term experiment, sowing density was adjusted to 450 viable seeds per $\mathrm{m}^{2}$ for winter wheat that is $240 \mathrm{~kg} \mathrm{ha}^{-1}$ seeds. For maize, recommended density was $23 \times 70 \mathrm{~cm}$ that is approximately 60.000 plants per hectare.

In the fertilized treatments, nitrogen mineral fertilizers were applied every year in the amount of $100 \mathrm{~kg} / \mathrm{ha}$ for wheat and sunflower, and $120 \mathrm{~kg} / \mathrm{ha}$ for maize. The amount of applied $\mathrm{P}$ and $\mathrm{K}$ depended on agrochemical analyses performed every year. Soyabean crops were not directly treated with fertilizers, but with microbiological fertilizer Nitragin.

The herbicide used for controlling the emergence of sorghum (Sorghum halepense (L.) Pers.) is glyphosate applied every year in July after wheat harvest. Also, herbicides 2.4D and iodosulfuron-methyl-sodium + amidosulfuron were introduced in 2000 for weed control in winter wheat.

Weed control in maize was based on S-metolachlor $(960 \mathrm{~g} / \mathrm{l})$ dose of $1.4 \mathrm{l} / \mathrm{ha}$ and $375 \mathrm{~g} / \mathrm{l} \mathrm{S}$-Metolachlor $+125 \mathrm{~g} / \mathrm{l}$ Terbuthylazine $+37.5 \mathrm{~g} / \mathrm{l}$ Mesotrione dose of 3.5-4 1/h. 
During the vegetation season, Sorghum and other narrow-leaved weeds were controlled by applying Nicosulfuron or Rimsulfuron 50-60 g/ha. During the vegetation season of maize, inter-row cultivation was carried out two times at 3-5 leaf stage and 5-7 leaf stage.

Determination and nomenclature of weed species was done according to Josifović (1986) and Tutin et al. (1980). Life forms are given according to Ujvárosi (1973). Counting of the plants, on randomly chosen area of $1 \mathrm{~m}^{2}$, in all treatments of experiment was done three times during the vegetation period, in relation to the phenological development of winter wheat $(\mathrm{BBCH} 30, \mathrm{BBCH} 53, \mathrm{BBCH} 85)$ and maize $(\mathrm{BBCH} 11$, $\mathrm{BBCH} 55, \mathrm{BBCH} 89$ ) according to decimal $\mathrm{BBCH}$ (Biologische Bundesanstalt, Bundessortenamt und Chemische Industie) scale, with three repetitions.

Bioindicator values (ecological indices) for the main ecological factors (climate indicators: temperature $-\mathrm{T}$, continentality $-\mathrm{K}$ and light $-\mathrm{L}$; soil indicators: moisture $-\mathrm{F}$, reaction $-\mathrm{R}$, nutrients $-\mathrm{N}$, humus $-\mathrm{H}$ and aeration $-\mathrm{D}$ ) were analyzed based on the values given by Landolt (2010). Plant species were characterised by a specific value of the ecological index which determines the ecological optimum for a particular species compared with some habitat traits. Values of the ecological indices are expressed on the scale from 1 to 5 , where 1 stands for minimum requirements and 5 for maximum requirements. For gaining the better insight in the ecological conditions based on bioindicator values, abundance of present weed species was taken into account. Hence, values of ecological indices for every weed species were multiplied by the average number of individuals of that species in the given variant of the experiment. Obtained values were added together and divided by the average weed density of all of the weed species in the analysed variant of the experiment, thence, the average value of every ecological index on all of the variants of the experiment was acquired.

The difference in the number of weed species between different treatments of crop rotation and crops were determined using t-test. The differences in the number of ind $/ \mathrm{m}^{2}$ of different weed species and differences in weed infestation of different crop rotation were determined using ANOVA and Duncan test, respectively. The relationship between ecological indices and treatments was examined using Cluster and Correspondent analyses. All statistical analyses were performed using STATISTICA 13.2 software (Dell ${ }^{\mathrm{TM}}$ Statistica ${ }^{\mathrm{TM}} 13.2$ University License).

\section{Results}

\section{Weed composition}

During the two-year study of weed flora in wheat and maize crops in long-term crop rotations at the experimental field Rimski Šančevi, a total of 35 weed species were identified (Table 2). The study showed that, out of this total number of weeds, 33 weed species were identified in the first year in wheat crops, including 32 weed species from the class of dicotyledon (Magnoliopsida) and only one species (Sorghum halepense) from the class of monocotyledon (Liliopsida). In the second year, only 14 species were recorded in maize crops, including 13 species from the class of dicotyledons and (the same as in wheat crops) only one species (Sorghum halepense) from the monocotyledon class. During the two studied years, 12 weed species were identified in both wheat and maize, and there were 21 differential species in wheat crops, while the species Amaranthus retroflexus and Xanthium italicum were found only in maize. Although 
there were not any species recorded in all treatments of crop rotation during the twoyear period, Sorghum halepense stood out as the most frequent species as it was identified in $11(79 \%)$ crop rotation treatments. It is important to note that the studied weed flora included seven species (Amaranthus retroflexus, Ambrosia artemisiifolia, Datura stramonium, Helianthus tuberosus, Oxalis stricta, Sorghum halepense and Xanthium italicum) from the category of invasive plants (DAISIE, 2008; Lazarević et al., 2012).

In both studied years, the biological spectrum (Fig. 2) was characterized by therophyte $(\mathrm{T})$ and geophyte $(\mathrm{G})$ life forms. The analysis showed that therophytes predominated $(82.85 \%$; 29 species), while the most abundant were T4 therophytes $(42.86 \% ; 15$ species $)$, i.e. annual plants that germinate in spring and mature at the end of summer, and T2 therophytes $(22.86 \% ; 8$ species $)$, i.e. annual plants that germinate in autumn and early spring, and mature at the beginning of summer. Perennial plants, geophytes, were less abundant $(17.14 \% ; 6$ species). In the first studied year, the biological spectrum in wheat crops showed almost identical life form distribution, absolutely dominated by therophytes $(81.83 \% ; 27$ species), with T4 $(39.39 \%, 13$ species) and T2 therophytes $(24.24 \% ; 8$ species) being most abundant, while geophytes accounted for only $18.2 \%$ (6 species) of the identified life forms. In the second studied year, the biological spectrum of weed flora in maize crops also had very similar life form distribution, with dominance of therophytes $(71.42 \% ; 10$ species), including $50 \%$ of T4 therophytes, and a higher percentage of geophytes (28.28\%, 4 species) (Fig. 2).

The highest number of weed species (20) was recorded in wheat crops grown in unfertilized two-year rotation, 15 species were found in wheat cultivated in two-year rotation and 14 species in wheat grown in monoculture (Fig. 3). Considering the differences in the average number of weed species between different wheat treatments (t-test), statistically highly significant and statistically significant differences were found between the abovementioned unfertilized two-year rotation, two-year rotation and monoculture of wheat compared to other crop rotation treatments (Table 3). The lowest floristic diversity was found in maize crops grown in monoculture and four-year rotation, where only 5 weed species were recorded. Considering the differences in the average number of weed species between individual maize treatments (t-test), statistically significant differences were found only between monoculture and two-year and three-year rotation with the application of organic fertilizers, and between two-year and three-year rotation with the application of organic fertilizers and four-year rotation (Table 3). In the second year, the number of weed species in maize was significantly reduced, with the highest reduction of $70 \%$ recorded in unfertilized two-year rotation, monoculture (64\%), followed by two-year rotation (64\%), four-year rotation (44\%) and unfertilized three-year rotation (42\%). Slightly smaller differences in the number of weed species were determined between wheat and maize grown in three-year rotation and three-year rotation with the application of organic fertilizers (30\% and 28\%, respectively). Statistical data analysis showed that the differences in the number of weed species found in wheat and maize crops are statistically highly significant (Table 4).

\section{Weed infestation}

Considering the level of weed infestation (Fig. 4), the highest values were determined in the treatments of monoculture in wheat crops, where the average number 
of ind $/ \mathrm{m}^{2}$ was 490.47 , and maize crops, where the level of weed infestation was $111.98 \mathrm{ind} / \mathrm{m}^{2}$. These values were the highest recorded values for wheat and maize considering all treatments of crop rotation. Although the highest level of weed infestation was recorded in monoculture for both crops, it should be noted that maize cultivated in monoculture showed $75 \%$ lower level of weed infestation compared to wheat. High levels of weed infestation were recorded also in wheat crops grown in the treatment of unfertilized three-year rotation $\left(198.61 \mathrm{ind} / \mathrm{m}^{2}\right)$, two-year rotation $\left(186.03 \mathrm{ind} / \mathrm{m}^{2}\right)$, unfertilized two-year rotation $\left(124.57 \mathrm{ind} / \mathrm{m}^{2}\right)$ and three-year rotation with the application of organic fertilizer $\left(101.15 \mathrm{ind} / \mathrm{m}^{2}\right)$. The lowest values of weed infestation in wheat crops were determined in the treatments of three-year rotation $\left(39.93 \mathrm{ind} / \mathrm{m}^{2}\right)$ and four-year rotation $\left(52.83 \mathrm{ind} / \mathrm{m}^{2}\right)$. Weed infestation in maize, with the exception of monoculture, was at a significantly lower level and was around $36 \mathrm{ind} / \mathrm{m}^{2}$ in the treatments of unfertilized two-year rotation, unfertilized three-year rotation, and four-year rotation, while the lowest weed infestation was recorded in the treatment of intensive two-year rotation $\left(17.31 \mathrm{ind} / \mathrm{m}^{2}\right)$ and three-year rotation with the application of organic fertilizer $\left(20.86 \mathrm{ind} / \mathrm{m}^{2}\right)$. It is also interesting to point out that the level of weed infestation in maize is considerably lower compared to the same treatments of crop rotation in wheat: by $91 \%$ in two-year rotation, $82 \%$ in unfertilized three-year rotation, $79 \%$ in three-year rotation with the application of organic fertilizer, $70 \%$ in unfertilized two-year rotation, $48 \%$ in three -field rotation and by $32 \%$ in fouryear rotation.

Statistical analysis indicated statistically significant difference between the overall weed infestation found in wheat (all treatments) and weed infestation in maize crops (all treatments) (Table 4).

Statistical analysis (Table 5), of the level of weed infestation in different crops in different treatments of the experiment in the first year in wheat indicated statistically highly significant difference between weed infestation in wheat monoculture and all other crop rotation treatments. In the second year, statistically significant difference was determined in maize crops also only for weed infestation in maize monoculture compared to other crop rotation treatments.

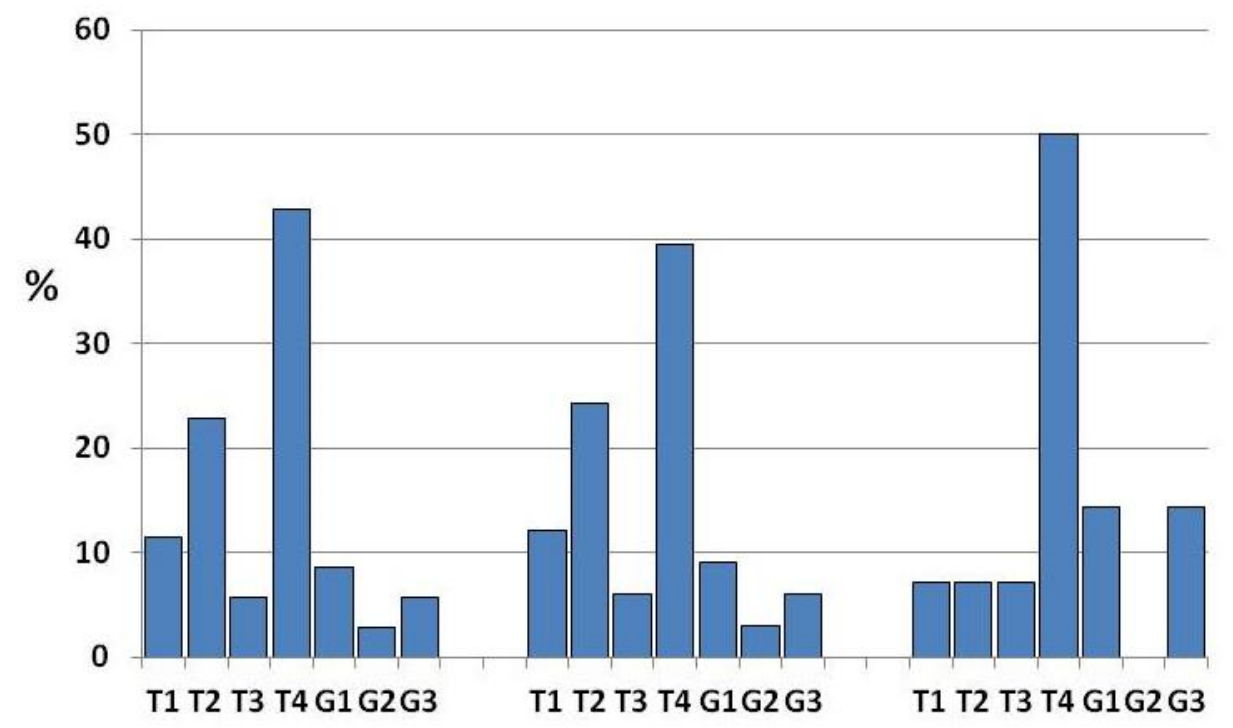

Figure 2. Biological spectrum of weed flora (2010 and 2011) 


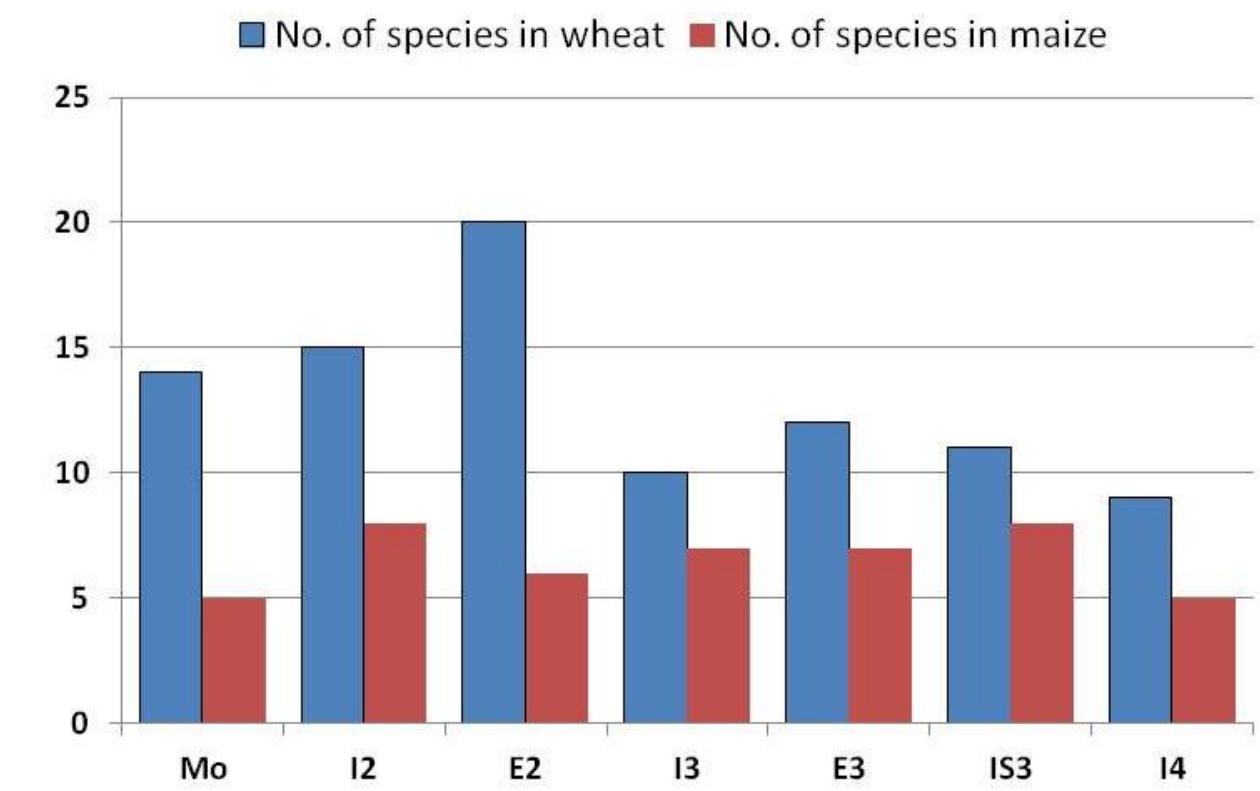

Figure 3. Number of weed species in wheat (2010) and maize (2011) in different crop rotations

Table 2. Review of weeds with the average number of individuals per square meter in wheat (2010) and maize (2011) in different variants of the experiment

\begin{tabular}{|c|c|c|c|c|c|c|c|c|c|c|c|c|c|c|c|}
\hline \multirow{2}{*}{ Plant species } & \multirow{2}{*}{$\begin{array}{c}\text { Life } \\
\text { form }\end{array}$} & \multicolumn{2}{|c|}{ Mo } & \multicolumn{2}{|c|}{$\mathbf{I 2}$} & \multicolumn{2}{|c|}{$\mathbf{E 2}$} & \multicolumn{2}{|c|}{ I3 } & \multicolumn{2}{|c|}{ E3 } & \multicolumn{2}{|c|}{ IS3 } & \multicolumn{2}{|c|}{ I4 } \\
\hline & & $\mathbf{W}$ & M & $\mathbf{W}$ & $\mathbf{M}$ & $\mathbf{W}$ & M & $\mathbf{W}$ & $\mathbf{M}$ & $\mathbf{W}$ & $\mathbf{M}$ & $\mathbf{W}$ & $\mathbf{M}$ & $\mathbf{W}$ & $\mathbf{M}$ \\
\hline 1. Adonis aestivalis $\mathrm{L}$. & $\mathrm{T} 2$ & 0.44 & & & & & & & & & & & & 0.44 & \\
\hline 2. Amaranthus retroflexus $\mathrm{L}$. & $\mathrm{T} 4$ & & & & 4.44 & & & & 2.66 & & & & & & 6.22 \\
\hline 3. Ambrosia artemisiifolia $\mathrm{L}$. & $\mathrm{T} 4$ & & & & 5.33 & 29.55 & 1.78 & & 1.78 & 77.77 & 4 & 2.66 & 0.89 & & \\
\hline 4. Anagallis arvensis $\mathrm{L}$. & $\mathrm{T} 4$ & & & & & 0.44 & & & & & & & & & \\
\hline 5. Anagallis femina Mill. & $\mathrm{T} 4$ & & & & 0.44 & 0.44 & & & & & & & & & 0.89 \\
\hline 6. Bilderdykia convolvulus (L.) Dum. & $\mathrm{T} 4$ & 59.11 & & 25.66 & & 2.22 & & 5.33 & & 2.22 & & 15 & & 6.21 & \\
\hline 7. Capsella bursa-pastoris (L.) Medik. & $\mathrm{T} 1$ & 31.11 & & 0.44 & & 0.44 & & & & & & 1.77 & & & \\
\hline
\end{tabular}

APPLIED ECOLOGY AND ENVIRONMENTAL RESEARCH 18(3):4775-4790.

http://www.aloki.hu • ISSN 15891623 (Print) • ISSN 17850037 (Online)

DOI: http://dx.doi.org/10.15666/aeer/1803_47754790

( 2020 , ALÖKI Kft., Budapest, Hungary 
8. Centaurea cyanus $\mathrm{L}$

9. Chenopodium album $\mathrm{L}$.

10. Chenopodium hybridum L.

11. Cirsium arvense (L.) Scop.

12. Consolida regalis S.F. Gray.

13. Convolvulus arvensis $\mathrm{L}$.

14. Datura stramonium L.

15. Euphorbia helioscopia L.

16. Fumaria officinalis L

17. Galeopsis tetrahit $\mathrm{L}$.

18. Galium aparine $\mathrm{L}$

19. Helianthus tuberosus $\mathrm{L}$.

20. Lamium amplexicaule $\mathrm{L}$

21. Lathyrus tuberosus $\mathrm{L}$

22. Lithospermum arvense (L.) Vahl.

23. Medicago lupulina $\mathrm{L}$

24. Oxalis stricta $\mathrm{L}$

25. Papaver rhoeas $\mathrm{L}$

26. Polygonum aviculare $\mathrm{L}$.

27. Ranunculus arvensis $\mathrm{L}$.

28. Sinapis arvensis $\mathrm{L}$.

29. Solanum nigrum L.

30. Sorghum halepense (L.) Pers.

31. Stachys аппиа L.

32. Stellaria media (L.) Vill.

33. Veronica hederifolia L.

34. Viola arvensis Murr.

35. Xanthium italicum L.

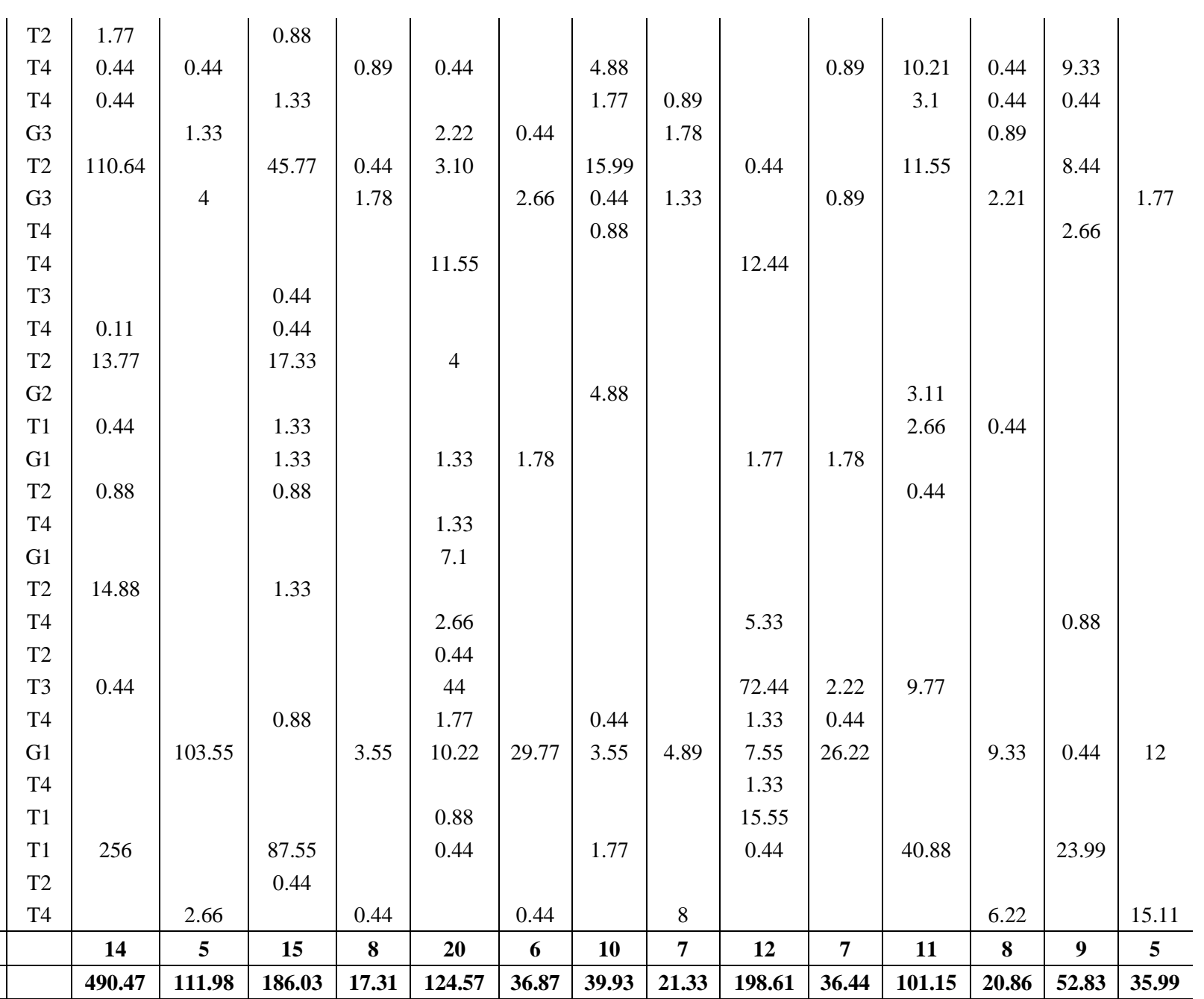

\begin{tabular}{|l|l|}
\hline 490.47 & 111.98 \\
\hline
\end{tabular}

W - wheat; M-maize; Mo - monoculture; I2 - intensive (fertilized) two-year rotation; E2 - extensive (unfertilized) two-year rotation; E3 - extensive (unfertilized) three-year rotation; IS3 - threeyear rotation with the application of organic fertilizers; I4 - intensive four-year rotation with the application of organic and mineral fertilizers; $\mathrm{T}-$ therophyte; $\mathrm{G}$ - geophyte 
Table 3. Significance of the differences in the number of weed species between different treatments of crops rotations and crops (t-test)

\begin{tabular}{c|c|c|c|c|c|c}
\hline Crop rotation & I2 & E2 & I3 & E3 & IS3 & I4 \\
\hline \multicolumn{6}{c}{ Wheat } \\
Mo & & $0.001^{* *}$ & $0.008^{* *}$ & & $0.021^{*}$ & $0.017^{*}$ \\
I2 & & $0.003^{* *}$ & $0.003^{* *}$ & $0.021^{*}$ & $0.008^{* *}$ & $0.009^{* *}$ \\
E2 & & & $0.000^{* *}$ & $0.000^{* *}$ & $0.000^{* *}$ & $0.001^{* *}$ \\
\hline \multicolumn{7}{c}{ Maize } \\
Mo & $0.021^{*}$ & & & $0.021^{*}$ & \\
I2 & & & & & $0.021^{*}$ \\
IS3 & & & & & $0.021^{*}$ \\
\hline
\end{tabular}

$* * \mathrm{p}<0.01, * \mathrm{p}<0.05$

Table 4. Significance of differences between the examined parameters

\begin{tabular}{c|c|c|c}
\hline Examined parameters & df & t-value & $\mathbf{p}$ \\
\hline No. of weed species in wheat / No. of weed species in maize & 12 & 4.30364 & $0.00^{* *}$ \\
Average no. of ind $/ \mathrm{m}^{2}$ in wheat / Average no. of ind $/ \mathrm{m}^{2}$ in maize & 12 & 2.19914 & $0.04^{*}$ \\
\hline
\end{tabular}

$* * \mathrm{p}<0.01, * \mathrm{p}<0.05$

Table 5. Significance of differences in weed infestation (ind $\mathrm{m}^{-2}$ ) in different treatments of crop rotation (ANOVA, Duncan test)

\begin{tabular}{c|c|c|c|c|c|c}
\hline Crop rotation & I2 & E2 & I3 & E3 & IS3 & I4 \\
\hline \multicolumn{7}{c}{ Wheat } \\
\hline Mo & $0.002^{* *}$ & $0.003^{* *}$ & $0.000^{* *}$ & $0.002^{* *}$ & $0.000^{* *}$ & $0.000^{* *}$ \\
\hline \multicolumn{7}{c}{ Maize } \\
\hline Mo & $0.013^{*}$ & $0.027^{*}$ & $0.015^{*}$ & $0.034^{*}$ & $0.016^{*}$ & $0.039^{*}$ \\
\hline \multicolumn{7}{c}{ Two-year period } \\
\hline Mo & $0.002^{* *}$ & $0.001^{* *}$ & $0.000^{* *}$ & $0.006^{* *}$ & $0.000^{* *}$ & $0.000^{* *}$ \\
\hline
\end{tabular}

$* * \mathrm{p}<0.01,{ }^{*} \mathrm{p}<0.05$

Significance of the difference in the number of individuals in certain weed species was analysed using ANOVA and Duncan's test, indicating statistically highly significant differences in the number of ind $/ \mathrm{m}^{2}$ for Consolida regalis (Fig. 5, species 12) and Veronica hederifolia (Fig. 5, species 33), which had the greatest influence on weed infestation in wheat crops compared to other weed species, and the species Sorghum halepense (Fig. 5, species 30), whose number of ind $/ \mathrm{m}^{2}$ in maize crops was also statistically highly significant compared to other identified species. In addition, based on the number of $\mathrm{ind} / \mathrm{m}^{2}$, the species Ambrosia artemisiifolia, Bilderdykia convolvulus and Sinapis arvensis (Fig. 5, species 3, 6 and 28, respectively) also had statistically significant influence on weed infestation in wheat. 


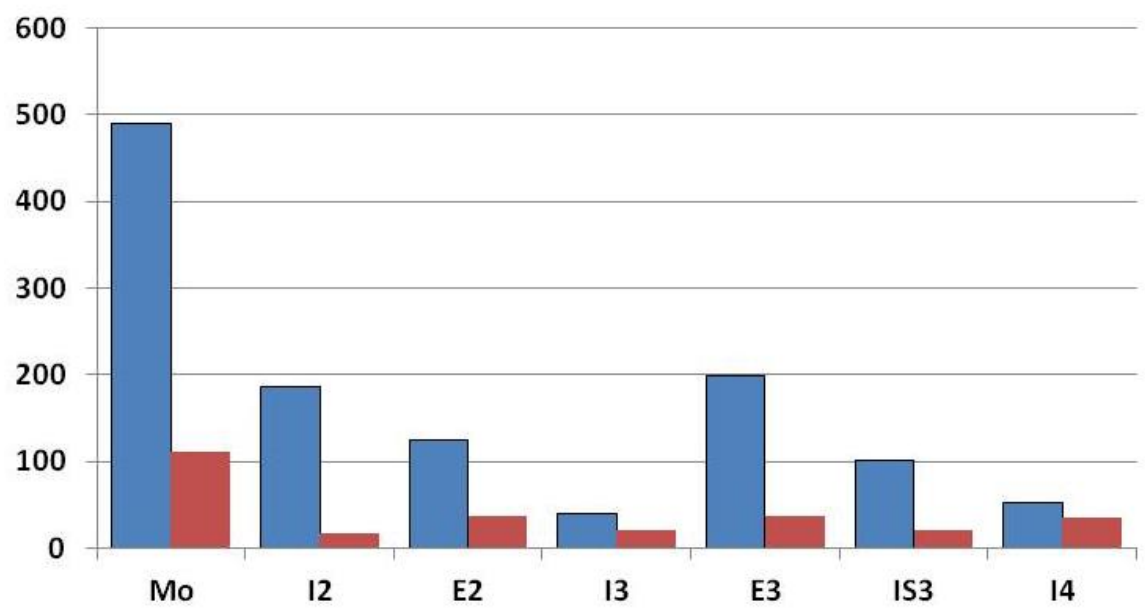

Figure 4. Average weed infestation in wheat (2010) and maize (2011) in different crop rotations

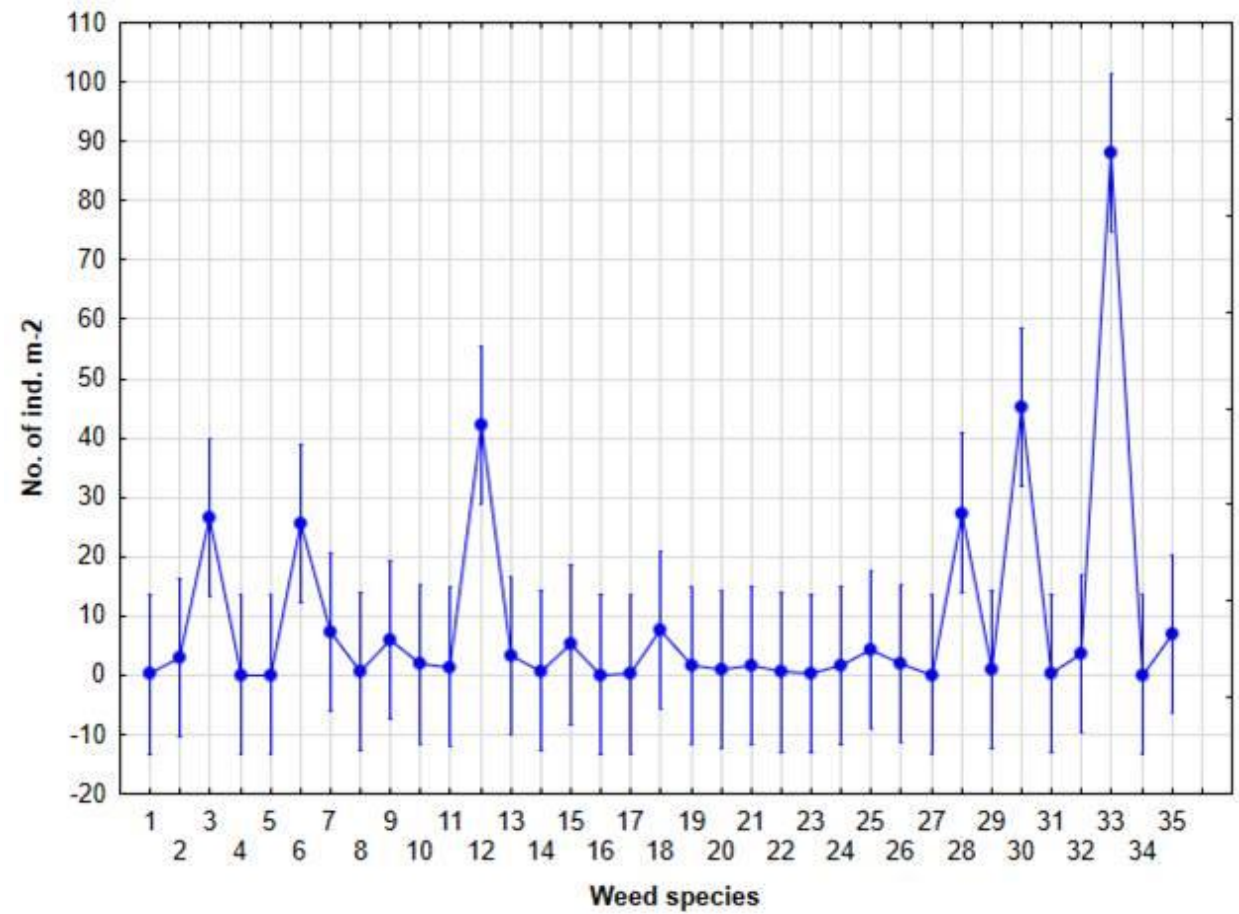

Figure 5. Significance of differences in the number of individuals per square meter (2010 and 2011) of different weed species (ANOVA)

\section{Weeds as bioindicators}

Apart from determining the basic meteorological and chemical properties of the soil in the studied area (Table 1; Fig. 1), indirect ecological analysis was also carried out based on the ecological indicator values of the identified weed species.

In all crop rotation treatments, the average values of climate indicators were favourable: the value of the ecological index for temperature suggested favourable temperature conditions $\left(T_{\bar{x}}=4.4\right)$, and the value of the ecological index for light 
showed favourable light regime $\left(\mathrm{L}_{\bar{x}}=3.76\right)$, which is in line with the mean value of the continentality index which indicated subcontinental conditions $\left(K_{\bar{x}}=2.73\right)$. Soil indicators suggested relatively favourable moisture content of the substrate in the studied crop rotation treatments $\left(\mathrm{F}_{\overline{\mathrm{x}}}=2.48\right)$, slightly acidic to neutral values of the chemical reaction of the substrate $\left(\mathrm{R}_{\overline{\mathrm{x}}}=3.54\right)$, fertile soil $\left(\mathrm{N}_{\overline{\mathrm{x}}}=3.99\right)$, with medium content of humus $\left(\mathrm{H}_{\bar{x}}=3\right)$ and well aerated $\left(\mathrm{D}_{\overline{\mathrm{x}}}=2.84\right)$ (Table 6$)$. However, certain differences, although not statistically significant (t-test), related to ecological conditions (expressed by bioindicator values) were found between different crop rotation treatments. Thus, four clusters were distinguished: first included fertilized wheat crop rotations, second included maize treatments in monoculture and unfertilized treatments, third cluster included fertilized maize treatments, and fourth cluster was formed of unfertilized wheat treatments (Fig. 6). Correspondent analysis also showed that some groups and types of treatments differ in relation to certain ecological indicators (Fig. 7). Specifically, clustering of fertilized wheat treatments was more intensively influenced by the moisture content in the substrate $(\mathrm{F})$ and partly by continentality $(\mathrm{K})$, while the nutrient content $(\mathrm{N})$ affected clustering of fertilized maize treatments. Clustering of maize monoculture and unfertilized treatments was influenced by brightness (L) and substrate reaction $(\mathrm{R})$, while aeration $(\mathrm{D})$ and humus content $(\mathrm{H})$ influenced clustering of unfertilized wheat treatments.

\section{Discussion}

Studying agrophytocenoses and their floristic composition is an important component in global biodiversity monitoring, as agroecosystems are characterised by strong anthropogenic influence and constant intensification of agricultural production (Nowak and Nowak, 2013). This study indicated significant differences in the composition of weeds in wheat and maize crops. In addition to 12 species common to both crops, as many as 21 species were recorded only in wheat, while the species Amaranthus retroflexus and Xanthium italicum were recorded only in maize (Table 2). The species which stood out in terms of the abundance in both crops was Sorghum halepense, which was found in $79 \%$ of the experimental treatments. These floristic differences were most likely a result of specific ecological conditions related to the species of crops, their rotation treatment and application of different cropping practices, as was noted also by Hosseini et al. (2014) and Campiglia et al. (2018). Since it is known that crop rotation reduces floristic diversity (Moss et al., 2004; Randy, 2005; Nikolić et al., 2018), this study also included analysis of weed flora in individual treatments of crop rotation. Statistical data analysis showed that the differences in the number of weed species found in wheat and maize crops are statistically highly significant (Table 4), indicating that crop rotation and crop species influence the structure of weed flora (Koocheki et al., 2009; Nikolić et al., 2018).

It is important to note that, according to DAISIE database (www.europe-aliens.org) and Lazarević et al. (2012), there were seven invasive alien species in the weed flora of the studied area (Amaranthus retroflexus, Ambrosia artemisiifolia, Datura stramonium, Helianthus tuberosus, Oxalis stricta, Sorghum halepense and Xanthium italicum). Due to their capability to highly successfully reproduce and spread to new areas, they are undesirable and their dynamics should be closely monitored (Richardson et al., 2000; Pyšek et al., 2004), as their spreading can have negative ecological, economic and health impacts. 


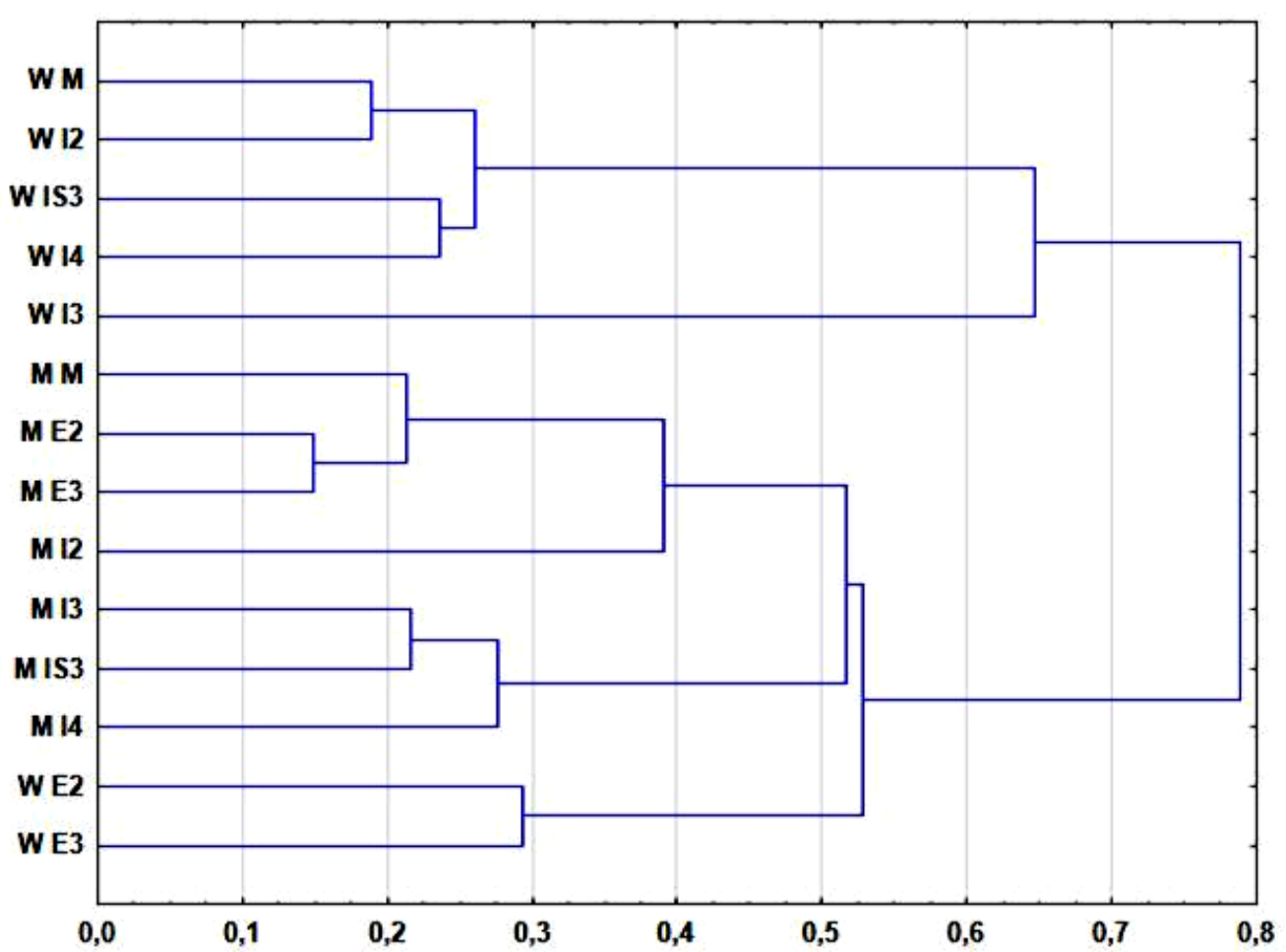

Figure 6. Dendrogram of different treatments of crop rotation based on ecological indices

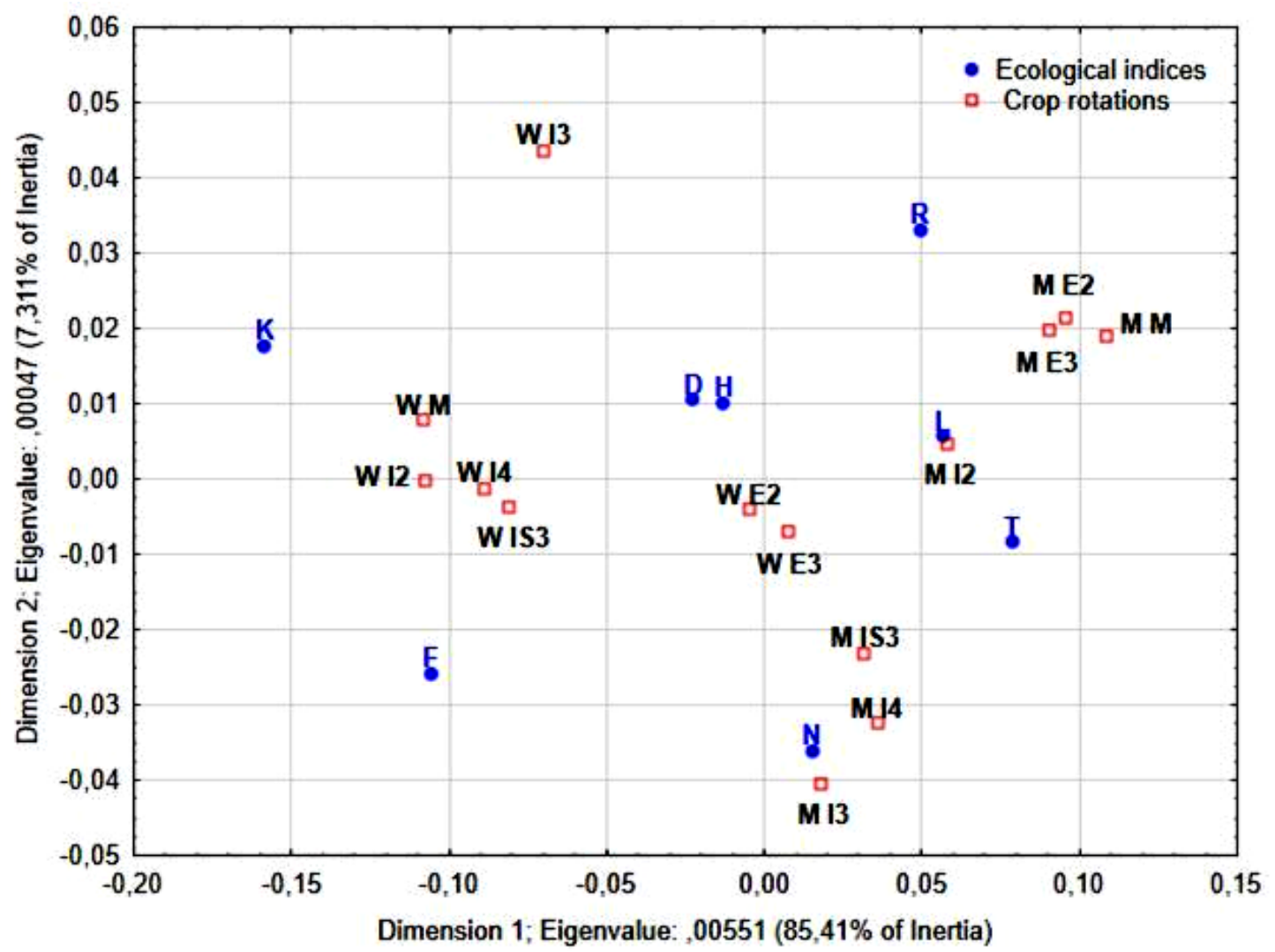

Figure 7. Biplot of different treatments of crop rotation and ecological indices 
Table 6. Average values of ecological indices in different variants of the experiment

\begin{tabular}{|c|c|c|c|c|c|c|c|c|c|c|c|c|c|c|c|c|c|}
\hline \multirow{2}{*}{$\begin{array}{l}\text { Ecological } \\
\text { index }\end{array}$} & \multicolumn{2}{|c|}{ Mo } & \multicolumn{2}{|c|}{$\mathbf{I 2}$} & \multicolumn{2}{|c|}{ E2 } & \multicolumn{2}{|c|}{ I3 } & \multicolumn{2}{|c|}{ E3 } & \multicolumn{2}{|c|}{ IS3 } & \multicolumn{2}{|c|}{ I4 } & \multirow{2}{*}{ Wheat } & \multirow{2}{*}{ Maize } & \multirow{2}{*}{$\overline{\mathbf{x}}$} \\
\hline & $\mathbf{W}$ & M & W & M & $\mathbf{W}$ & M & $\mathbf{W}$ & $\mathbf{M}$ & $\mathbf{W}$ & M & W & M & W & M & & & \\
\hline $\mathbf{T}$ & 3.8 & 4.94 & 3.88 & 4.6 & 4.22 & 4.89 & 4 & 4.73 & 4.32 & 4.82 & 4.02 & 4.76 & 3.83 & 4.84 & 4.01 & 4.8 & 4.4 \\
\hline $\mathbf{K}$ & 3.26 & 2.11 & 3.28 & 2.38 & 2.65 & 2.26 & 3.34 & 2.67 & 2.56 & 2.24 & 3.15 & 2.66 & 3.1 & 2.57 & 3.05 & 2.41 & 2.73 \\
\hline $\mathbf{L}$ & 3.22 & 3.98 & 3.19 & 3.97 & 3.85 & 3.99 & 3.83 & 3.92 & 3.92 & 4 & 3.45 & 3.96 & 3.38 & 4 & 3.55 & 3.97 & 3.76 \\
\hline $\mathbf{F}$ & 2.73 & 2.05 & 2.78 & 2.22 & 2.64 & 2.06 & 2.58 & 2.59 & 2.56 & 2.09 & 2.72 & 2.43 & 2.68 & 2.53 & 2.67 & 2.28 & 2.48 \\
\hline $\mathbf{R}$ & 3.26 & 3.96 & 3.28 & 3.62 & 3.6 & 3.93 & 3.56 & 3.46 & 3.49 & 3.87 & 3.25 & 3.57 & 3.18 & 3.58 & 3.37 & 3.71 & 3.54 \\
\hline $\mathbf{N}$ & 3.77 & 3.99 & 3.82 & 3.97 & 3.98 & 3.96 & 3.6 & 4.38 & 3.99 & 3.95 & 3.88 & 4.3 & 3.83 & 4.4 & 3.84 & 4.14 & 3.99 \\
\hline H & 3 & 3 & 3 & 3 & 2.99 & 3 & 3 & 3 & 3 & 3 & 3 & 3 & 3 & 3 & 3 & 3 & 3 \\
\hline D & 2.94 & 2.9 & 2.79 & 2.79 & 2.76 & 2.74 & 2.73 & 2.71 & 2.97 & 2.85 & 2.94 & 2.7 & 3 & 2.9 & 2.88 & 2.8 & 2.84 \\
\hline
\end{tabular}

$\mathrm{T}$ - temperature; $\mathrm{K}$ - continentality; $\mathrm{L}$ - light; $\mathrm{F}$ - moisture; $\mathrm{R}$ - reaction; $\mathrm{N}$ - nutrients; $\mathrm{H}$ - humus; $\mathrm{D}$ - aeration. Mo monoculture; I2 - intensive (fertilized) two-year rotation; E2 - extensive (unfertilized) two-year rotation; E3 - extensive (unfertilized) three-year rotation; IS3 - three-year rotation with the application of organic fertilizers; I4 - intensive four-year rotation with the application of organic and mineral fertilizers

The biological spectrum was absolutely dominated by therophytes, which accounted for $82.85 \%$ and $71.42 \%$ of the analyzed flora in wheat and maize, respectively (Fig. 2). McIntyre et al. (1995) also found that therophyte life form dominated in arable agricultural land. Such life form distribution is common for weed flora under the strong influence of cropping practices (Kovačević et al., 2008).

Considering weed infestation in different treatments in the studied two-year period (in both wheat and maize), the highest average values were recorded in wheat monoculture (490.47 ind $/ \mathrm{m}^{2}$ ) and maize monoculture (111.98 ind $/ \mathrm{m}^{2}$ ) (Table 2; Fig. 4), statistically highly significant difference was found also only between monoculture and other crop rotation treatments (Table 5), which is in line with the findings of other authors who reported that crop rotation and soil cultivation result in reduction of weed density and biomass (Demjanova et al., 2009). The weed species which, due to their abundance, had the greatest influence on weed infestation were Consolida regalis and Veronica hederifolia in wheat, and Sorghum halepense in maize, which was statistically significant in relation to other weed species.

Since the composition of weed flora depends on the ecological characteristics of the environment and the intensity of anthropogenic influence (Šilc, 2010; Jarić et al., 2015), different weed species can be found in different crop rotation treatments, so some treatments differ considerably in relation to their floristic composition. However, our results indicate that higher floristic diversity is not proportional to the level of weed infestation in crops (Table 2).

Knowing that each plant species has certain requirements regarding the ecological characteristics of the habitat, which are expressed by ecological indices (bioindicator values), it is possible to make ecological assessment of the habitat characteristics and the site class. It should be noted that the assessment takes into consideration the average abundance for each weed species, so that the obtained values of the analysed ecological indices represent a reliable indicator of ecological conditions in studied crop rotation treatments.

Therefore, the obtained results are in line with the findings of Šilc (2010) and Jaric et al. (2015) who stress that the composition of weed flora depends on ecological characteristics of the environment and intensity of anthropogenic influence. Although the average ecological indicator values for the main environmental factors pointed to favorable light regime, $\mathrm{pH}$, nutrient content and soil aeration in all experimental 
treatments, there were some differences in ecological conditions, as was indicated by clustering of certain experimental treatments in four clusters (Fig. 6). It can be concluded that both the type of crop rotation, application of fertilizers and the species of crops had impact on ecological conditions of the studied experimental treatments, which resulted in their clustering and differentiation, expressed by the ecological indicator values of the weed species.

Studying weed flora in long-term crop rotations clearly showed that the structure of weed flora and the level of weed infestation depend on the applied cropping practices and crop rotation treatment. The experiment thus showed that the highest reduction of weed infestation in both crops was achieved in intensive (fertilized) three-year and fouryear rotations (Fig. 4), which is in line with results of previous studies (Smit and Gross, 2007; Milošev et al., 2014; Nikolić et al., 2018).

\section{Conclusion}

The obtained results on weed flora and weed infestation in this research are based on a long-term crop rotation experiment with some of the experimental treatments formed more than seven decades ago. The specific scientific contribution of this paper is that the habitat is characterized on the basis of the ecological indicator values of the determined weed species, and it is possible to identify specific crop rotation treatments in which a certain ecological characteristic has significant effect on weed infestation.

Considering the findings of this research and the results from literature (Smith and Gross, 2007; Koocheki et al., 2009), it can be concluded that the long-term effects of crop rotation are positive since this agricultural practice does not lead to increased weed abundance or development of weed communities that could be difficult to control. Crop rotation is justified also from the aspect of environmental protection, as it contributes to reduced application of chemicals, which is in line with generally accepted views on the preservation, sustainability and balanced use of agricultural land (Liebeman and Dyck, 1993; Milošev et al., 2014; Nikolić et al., 2018).

In the future research, the soil seed bank for these long-term experiments could be analysed. Thus, the prediction of the weed growth would be enabled which could ensure additional reduction and selection of the applied herbicides with the adequate crop rotation.

Acknowledgements. We are grateful to the Institute of Field and Vegetable Crops in Novi Sad for allowing us to work in their fields "Plodoredi".

\section{REFERENCES}

[1] Avola, G., Tuttobene, R., Gresta, F., Abbate, V. (2008): Weed control strategies for grain legumes. - Agronomy for Sustainable Development 28: 389-395.

[2] Barberi, P., Silvestri, N., Bonari, E. (1997): Weed communities of winter wheat as influenced by input level and rotation. - Weed Research 37: 301-313.

[3] Campiglia, E., Radicetti, E., Mancinelli, R. (2018): Floristic composition and species diversity of weed community after 10 years of different cropping systems and soil tillage in a Mediterranean environment. - Weed Research 58: 273-283.

[4] Delivering Alien Invasive Species Inventories for Europe (DAISIE) (2018): www.europe-aliens.org. - Accessed on 15 December 2018. 
[5] Demjanova, E., Macak, M., Đalović, I., Majernik, F., Tyr, Š., Smatana, J. (2009): Effects of tillage systems and crop rotation on weed density, weed composition and weed biomass in maize. - Agronomy Research 7: 785-792.

[6] Derksen, A. D., Andersen, L. R., Blackshaw, E. R., Maxwell, B. (2002): Weed dynamics and management strategies for cropping systems in the Northern Great Plains. Agronomy Journal 94: 174-185.

[7] HMZS (2020): Republic Hydrometeorological Service of Serbia. - www.hidmet.gov.rs (accessed on 09.04.2020).

[8] Hosseini, P., Karimi, H., Babaei, S., Mashhadi, H. R., Oveisi, M. (2014): Weed seed bank as affected by crop rotation and disturbance. - Crop Protection 64: 1-6.

[9] Jarić, V. S., Karadžić, D. B.; Vrbničanin, P. S., Mitrović, M. M., Kostić, A. O., Pavlović, Ž. P. (2015): Floristic and phytocoenological research of segetal plant communities in cultivated areas of southern Srem. - Archives of Biological Sciences 67: 591-609.

[10] Josifović, M. (ed.) (1986): Flora Republike Srbije. - Serbian Academy of Sciences and Arts, Beograd.

[11] Kim, D. S., Brain, P., Marshall, E. J. P., Caseley, J. C. (2002): Modelling herbicide dose and weed density effects on crop: weed competition. - Weed Research 42: 1-13.

[12] Koocheki, A., Nassiri, M., Alimoradi, L., Ghorbani, R. (2009): Effect of cropping systems and crop rotations on weeds. - Agronomy for Sustainable Development 29: 401408.

[13] Kovačević, D., Dolijanović, Ž., Oljača, S., Jovanović, Ž. (2008): The Effect of Crop Rotation on Weed Control. - Acta Herbologica 17: 23-38.

[14] Landolt, E. (ed.) (2010): Flora Indicativa. Ecological Indicator Values and Biological Attributes of the Flora of Switzerland and the Alps. - Haupt Verlag, Bern-Stuttgart-Wien.

[15] Lazarević, P., Stojanović, V., Jelić, I., Perić, R., Krsteski, B., Ajtić, R., Sekulić, N., Branković, S., Sekulić, G., Bjedov, V. (2012): Preliminarni spisak invazivnih vrsta u republici Srbiji sa opštim merama kontrole i suzbijanja kao potpora budućim zakonskim aktima. - Protection Nature 62: 5-31.

[16] McIntyre, S., Lavorel, S., Tremont, R. M. (1995): Plant life-history attributes: their relationship to disturbance response in herbaceous vegetation. - Journal of Ecology 83: 31-44.

[17] Milošev, D., Šeremešić, S., Đalović, I., Pejić, B., Ćirić, V. (2014): Assessing the agroecosystem performance in a long-term winter wheat cropping. - Contemporary Agriculture 63: 494-500.

[18] Moss, R. S., Storkey, J., Cussans, W. J., Perryman, A. M. S., Hewitt, V. M. (2004): Symposium The Broadbalk long-term experiment at Rothamsted: what has it told us about weeds? - Weed Science 52: 864-873.

[19] Nikolić, Lj., Milošev, D., Šeremešić, S., Đalović, I., Vuga Janjatov, V. (2012): Diversity of weed flora in wheat depending on crop rotation and fertilisation. - Bulgarian Journal of Agricultural Science 18: 608-615.

[20] Nikolić, Lj., Šeremešić, S., Milošev, D., Đalović, I., Latković, D. (2018): Weed infestation and biodiversity of winter wheat under the effect of long-term crop rotation. Applied Ecology and Environmental Research 16: 1413-1426.

[21] Nowak, S., Nowak, A. S. (2013): Weed communities of root crops in the Pamir Alai Mts, Tajikistan (Middle Asia). - Acta Societatis Botanicorum Poloniae 82: 135-146.

[22] Pyšek, P., Richardson, M. D., Rejmánek, M., Webstwer, L. G., Willianson, M., Kirschner, J. (2004): Alien plants in checklists and floras: towards better communication between taxonomists and ecologists. - Taxon 53: 131-143.

[23] Randy, L. A. (2005): A multy-tactic approach to manage weed population dynamics in crop rotations. - Agronomy Journal 97: 1579-1583.

[24] Richardson, M. D., Pyšek, P., Rejmanek, M., Barbour, G. M., Panetta, F. D., West, J. C. (2000): Naturalization and invasion of alien plants: concepts and definitions. - Diversity and Distribution 6: 93-107. 
[25] Smith, R. G., Gross, L. K. (2007): Assembly of weed communities along a crop diversity gradient. - Journal of Applied Ecology 44: 1046-1056.

[26] Suarez, A. S., De La Fuente, B. E., Ghersa, M. C., Leon, J. C. R. (2001): Weed community as an indicator of summer crop yield and site quality. - Agronomy Journal 93: 524-530.

[27] Šilc, U. (2010): Synanthropic vegetation: pattern of various disturbances on life history traits. - Acta Botanica Croatica 69: 215-227.

[28] Škorić, A., Filipovski, G., Ćirić, M. (1985): Klasifikacija zemljišta Jugoslavije. Academy of Sciences and Arts Bosnia and Herzegovina, Sarajevo.

[29] Teasdale, R. J., Mangum, W. R., Radhakrishnan, J., Cavigelli, A. M. (2004): Weed seedbank dynamics in three organic farming crop rotations. - Agronomy Journal 96: 1429-1435.

[30] Tutin, G., Heywood, V. H., Burges, N. A., Valentine, D. H., Walters, S. M., Webb, D. A. (eds.) (1980): Flora Europea, 1-5. - University Press, Cambridge, UK.

[31] Týr, Š. (2016): Actual weed infestation and sustainable farming systems in winter wheat. - Research Journal of Agricultural Science 48: 211-216.

[32] Ujvárosi, M. (1973): Gyomnövények. - Mezögazdasági Kiadó, Budapest.

[33] Woźniak, A., Soroka, M. (2015): Structure of weed communities occurring in crop rotation and monoculture of cereals. - International Journal of Plant Production 9: 487506. 